\title{
Analysis on Current Situation of Comprehensive Quality of Students in Fine Arts Major of University and Research on Methods of Promotion
}

\author{
Guohua Gao \\ Heihe University \\ Heihe, Heilongjiang, China
}

\begin{abstract}
Since the 21st century, people have higher requirements for higher education. Fine arts professional education meets development opportunities as well as new challenges. In teaching and management, teachers strive to train artistic creation ability and perfect personality of students, strengthen education in aesthetic value and aesthetic cultural quality and pay attention to letting students have ability to adapt to the society and sustainable development capacity, namely improve comprehensive quality of students and let them meet challenges confidently. This article makes in-depth analysis on "making efforts to cultivate fine arts educators with era characteristics and guide students to establish professional idea of fine arts teachers".
\end{abstract}

Keywords-fine arts; fine arts education; teachers of fine arts; comprehensive

\section{INTRODUCTION}

In recent years, the number of candidates and enrollment quantity of fine arts increase greatly, so the scale of fine arts major becomes increasingly large. Nowadays, higher education is popularize and provides big space for personal development in all directions. People are freer and freer to choose occupation. In this way, employment pressure of graduates in fine arts education increases. It has become a widespread phenomenon that people "change their profession". As instructor of fine arts students, the author deeply feels the heavy responsibility, deeply thinks how to endeavor to cultivate fine arts educators with era characteristics and guide students to establish professional idea of fine arts teachers, strive to train artistic creation ability and perfect personality of students, strengthen education aesthetic value and aesthetic cultural quality, and pay attention to letting students have ability to adapt to the society and sustainable development capacity. That is to say, improve comprehensive quality of students and let them meet challenges confidently.

\section{Guided by LAW of Higher ARt EduCATION, MAKE EFFORTS TO CUlTIVATE FINE ARTS EDUCATORS WITH ERA CHARACTERISTICS}

In the environment that higher art education gets unprecedented development, fine arts teachers shall fully seize opportunities and challenges and reform with keen determination, take four "must" in lecture of general secretary $\mathrm{Hu}$ Jintao in centennial anniversary of Tsinghua University as guidance, namely, "in order o comprehensively improve quality of higher education, we must vigorously improve the level of talents cultivation, must vigorously strengthen the ability of scientific research, must vigorously serve economic and social development and must vigorously promote innovation of cultural inheritance". Fine arts educators shall attach importance to researching universal law of higher education and special law of art education, respect personality development of students, carry out standard management, continuously establish and improve teaching management system that bases on talents cultivation, furthest create flexible and free space and atmosphere for creation and learning of students, pay attention to innovation to ensure that academic thinking and creative energy of students get development and cultivate excellent professional talents of fine arts education with era characteristics for our country.

Art needs innovation. Open teaching environment is very important for artistic creation. It can arouse enthusiasm of teachers and students to communicate and design, and then strengthen feeling of success and sense of competence of teachers and students and fully develop potential of people. Schools shall often organize and carry out various forms of cultural exchange activities. For example, employ some experts to give lectures in school, organize students to participate in some international and domestic design competition, strengthen communication of other related professional fields with other universities, and create an open teaching environment with strong atmosphere for students to design.

\section{AIM AT "SER VING THE SOCIETY", STRENGTHEN Pertinence of TAlents TRAining OBJeCtives of Fine ARTS}

Outline of the National Medium and Long Term Educational Reform and Development Plan (2010-2020) puts forward that it is necessary to take improvement of quality as core task of education reform and development and take strengthening of construction of teaching staff as an important content of safeguard measure, and points out that "strictly check qualification of teachers, improve teachers' quality and make efforts to build high-quality professional teacher team 
full of vigor, with noble ethics, exquisite business and reasonable structure". Teacher education is the basis for basic education to develop and the key factor to decide quality of education. Compared with other universities, influenced by elements such as region, society and humanity, local universities have few financial investment and poor comprehensive strength, weak regional advantages. Besides, compared with other majors, fine arts (teacher education) major belongs to special major, so it shall face reality, vigorously promote and meet requirements of education reform and development.

At present, cultivation of basic fine arts education talents in China lacks pertinence of education and excessively emphasizes independence of discipline. Basic fine arts education in middle and primary school is multidisciplinary basic fine arts education and comprehensive education of artistic accomplishment. Teaching contents contained by it shall make for healthy physical and mental development of primary and secondary school students as well as education and growth of them in the future. Therefore, in cultivation of students in fine arts major, it is necessary to consider cultivation standard of teaching talents from broader perspectives, instead of treating teaching of fine arts major from discipline-based thought. Talents of fine arts must have comprehensive professional knowledge of fine arts and relatively high cultural and artistic accomplishment. Basic professional abilities of fine arts talents include not only the ability of drawing, but also other professional knowledge closely related to it, such as artistic theory, social science and natural science, philosophy and aesthetics. Improving comprehensive cultural quality of students can make them better adapt to the society and basic art teaching in the future and aim at "serving the society".

\section{START With CULTIVATING INTERESTS OF STUdENTS} AND GUIDE STUDENTS TO ESTABLISH PROFESSIONAL IDEA OF FINE ARTS TEACHERS

Since the 21st century, people have higher requirements for higher education. Fine arts professional education meets development opportunities as well as new challenges. In July 2001, Ministry of Education officially issued Fine Arts Course Standard (Experimental Manuscript). The reform of fine arts course standard combines with current situation and problems of fine arts education at present in China, bases on referring to and absorbing successful experiences of course reform in foreign countries and implements comprehensive adjustment and optimization of structural contents, course system and future development trend of Chinese art education. With continuous strengthening of new curriculum standard reform of fine arts, the previous traditional teaching pattern cannot meet requirements of fine arts education development. "Professional teachers must have basic skills and ability to engage in education and teaching." Therefore, on training objectives and ways, high normal university of fine arts follows the principle of "organically combining learning of fine arts education theory with teaching practice". It gives new challenge for fine arts major in universities and has higher requirements for professional knowledge and skills of fine arts teachers. Teaching methods of high normal university of fine arts education namely fine arts major are flexible and diversified. When passing on experience in practical teaching, fine arts teachers in universities shall use different teaching methods according to ability of different students in receiving knowledge, psychological characteristics and employment choice and truly teach students in accordance of their aptitude by using developmental perspective. "Professional knowledge, professional skills and professional affection are main parts that form professional quality of teachers. Developmental level of the three aspects decides professional development level of teachers." Therefore, under the background of curriculum standard reform of fine arts, it has important significance in paying attention to "level of professional affection" and establishing professional idea through researching cultivation of teaching ability of students in fine arts education major in high normal university of fine arts. Traditional fine arts major in China pays close attention to training of professional skills. The occupational concept of students cultivated by them is that the status of painter is higher than that of fine arts teachers. This shows that in order to help students to establish professional idea of fine arts teachers, we shall consider specialty of fine arts discipline and emphasize its teacherstraining quality. More important, emphasize teachers-training quality of fine arts education major in moral education or guidance of "level of professional affection". For example, training objective of students in fine arts education is fine arts educators in middle and primary schools, and then cultivate art workers on this basis. Students in fine arts major will be cultivated into art workers in the future. Training objectives of them are different indeed. Fine arts teachers of universities shall adopt different educational thought and method and manner in teaching process. In courses of teaching basic skills and skill training, teachers shall teach techniques to students and emphasize "what to draw", "why to draw" and "what to teach" in the future; they should pay more attention to training correct aesthetic standard of students in fine arts major and interests of students in this major, concern students, teach them how to better appreciate and create and master means to analyze and criticize. In this way, it can strengthen comprehensive ability, expressive ability, ability to communicate and ability of value judgment of students, and then let students learn methods of content organization of teaching activities and lay foundation for them to become qualified fine arts teachers in middle and primary schools. The ideal of students will change from "painter" and "designer" to "fine arts teachers", truly love education cause, consciously establish correct professional idea of fine arts teachers according to standard for qualified fine arts teachers of basic education.

\section{IMPROVE StRENGTH OF ARTISTIC PRACTICE}

\section{A. Strengthen Practice Teaching in Class and Integrate Practice Teaching in Teaching of Professional Courses}

Practice teaching in class can improve comprehensive ability of students through truly combining with all links. In order to integrate with practical design, universities shall intensify practice teaching in class and combine practice teaching with teaching of professional course. The practice course hours should reach above $40 \%$. Teachers can introduce 
practical design into classroom in teaching and strengthen practicality and pertinence of courses. For example, cooperate with related design companies, bring social requirements into classroom teaching and directly use it in design teaching in class. In this way, it can strengthen practical ability, creative spirit and sense of competition of students and help to train team spirit and improve teaching quality as well as realize social value to some extent. In order to achieve this purpose, the most convenient and effective way is to set up studio of design of this major and undertake design tasks, introduce it into classroom and truly realize combination of industryuniversity- research.

In teaching, using design case to analyze is an effective method to strengthen practice teaching. Teachers can analyze term by term according to way of actual operation and point out common practice and problems that may appear. With concrete examples, it can strengthen perceptual knowledge of students, easier for students to accept, and help to improve comprehensive and analytical ability of students and achieve better effects.

Unceasingly improve evaluation criterion and evaluation method of practice teaching and adopt quantized marking criterion. Realize quantification of the whole practice teaching process, set assessment components and scores for each link of practice teaching according to different teaching requirements. The characteristics of marking criterion include that the score is clear, the comprehensive test has large coverage, the marking is reasonable, and it is not easy to get high scores. Besides, it completely eradicates the drawbacks that teachers mark randomly and base on their feeling in practice teaching. Quantized marking criterion is very necessary to test comprehensive ability of students, correctly reflect academic record of students and arouse enthusiasm of students in learning and it is powerful means to ensure normal proceeding of practice teaching.

\section{B. Let Students Go Out of the Classroom, Get Knowledge in Practice and Improve Design Ability}

Teachers should arrange a certain amount of off-campus practice lessons in teaching. Take forms such as investigation practice, labor service practice and graduation practice, let students accept various forms of practical education step by step. No matter for what kind of practice teaching activities, it is necessary to make adequate and effective preparations, carefully organize the whole process, carefully analyze feedback of practice effect from students, sum up experience, find out insufficient and lay foundation for practice teaching in the future.

Graduation design shall be arranged after graduation practice. In this way, students have accumulated certain practical experience in practice process. When doing graduation design, it will be closer to life and the scheme is more feasible. If condition permits, schools shall endeavor to directly link graduation design of students with design project of company, combine graduation design with reality and let students realize design value in the process of actual practice.

\section{CONCLUSION}

China has vast territory. The employment paths of graduates in fine arts major in universities are extensive, but the employment competition will be fierce as well. In the longterm strategy, universities must improve the quality of fine arts education, strengthen competitiveness of students in fine arts major and stick to the principle of putting equal emphasis on technology and art, cultivate art designers with integrated development, good ideological quality, skilled professional skill and scientific creative thinking. In this way, it can achieve sustainable development of art design education major in universities.

\section{REFERENCES}

[1] Chen Shanqing, etc. Theory on Moral Education in Life [M], Shenyang: Northeast Normal University Press, 2005

[2] Tao Xingzhi. Education Reform in China [M], Shanghai: Oriental Press, 1996.

[3] Tao Xingzhi. Complete Works of Tao Xingzhi (volume 1 and 11) [M], Chengdu: Sichuan People's Publishing House, 1991.

[4] Lu Hongmei. Aesthetic Analysis on Life-oriented Ideological and Political Education of University Students [J], Knowledge Economy, the 269th issue, 2013 (1).

[5] Jin Ying, Wang Ailing. Analysis on Capability System of Teachers [J], Theory and Practice of Education, 2000(04), 41-45.

[6] Luo Xiaofei. Discussion on Teaching Practice for Students of Fine Arts Education Major [J], Journal of Aba Teachers College, 2006 (2).

[7] Xiao Xinghua. Thinking on the Situation That the Present Fine Arts Education Major in Normal Universities Pays Attention to Skills and Thinks Little of Theory [J], Journal of Qiannan Normal College of Nationalities, 2006.

[8] Qiu Changpei. New Exploration on Development Tendency of Fine Arts Education [J], Journal of Sichuan Normal University (Social Science Edition), 1999 